Laura Fekonja

University of Belgrade

Faculty of Philology
UDC $371.3:: 811.163 .6 ' 243$

DOI https://doi.org/10.18485/fid.2017.7.ch4

\title{
THE CENTRE FOR SLOVENE AS A SECOND AND FOREIGN LANGUAGE: ACTIVITIES SUPPORTING THE MINORITIES LIVING IN SLOVENIA AND ABROAD
}

\begin{abstract}
Овај чланак представља главне активности Центра за словеначки као други страни језик, који постоји у оквиру Одељења за словеначке студије на Факултету уметности Универзитета у Љубљани. Чланови Центра главни фокус стављају на наставу словеначког као страног језика у иностранству, као и у Словенији. Осим тога, са Националним просветним институтом Републике Словеније они настоје да успоставе и развијају наставу словеначког као мањинског језика. Убрзани курсеви словеначког се организују за ученике основних и средњих школа, као и за ученике двојезичних школа. Дакле, основци и средњошколци, као и и старији имигранти, могу присуствовати настави словеначког језика. Деца имиграната, која су укључена у у словеначки образовни систем, као и њихови родитељи, представљају циљну групу за активности које организује Центар.
\end{abstract}

Кључне речи: словеначки као други страни језик, мањине у Словенији, Центар за словеначки као други страни језик.

\section{Introduction}

The Centre for Slovene as a Second/Foreign Language acts under the Department of Slovenian Studies at the Faculty of Arts in Ljubljana, which was founded in 1965, when the first Seminar of Slovene language, literature and culture was organised (within the Department of Slavic Languages and Literatures). At that time, some ten curious foreign Slavists participated in the event, but seven years later, in 1972, that number rose to 120 participants. This number has remained stable until this year in which the Seminar commemorates its 50" anniversary. The Seminar of Slovene language, literature and culture is one of the six programmes or activities of the Centre for Slovene as a Second/Foreign Language. Other programmes are: Slovene at Foreign Universities, Symposium Obdobja, Examination 
Centre, Slovene Language Courses, Education, Publishing, and Slovene for Children and Teenagers. The activities of the Centre for Slovene as a Second/Foreign Language are not focused on minorities alone, but there are certain programmes that are intended especially for them.

\section{Activities of the Centre for Slovene as a Second/Foreign Language, focused on minorities in Slovenia}

The Centre for Slovene as a Second/Foreign Language is a central Slovenian establishment that organises research on Slovene as a foreign language; developing appropriate infrastructure (at home and abroad); teaching Slovene as a foreign language; and educating teachers that teach Slovene as a second language in Slovenia and as a first language abroad. Slovenia has three officially acknowledged minorities: Italian, Hungarian (so called traditional minorities) and a Romany minority. These minorities are under constitutional protection (according to the 64 $4^{\text {th }}$ and 65 Article of the Constitution of the Republic of Slovenia). Nevertheless, members of these minorities are not the only residents of Slovenia whose mother tongue is not the Slovene language. The population of Slovenia consists (including Slovenian citizens) of citizens from 136 other countries. The majority of foreign citizens are citizens from one of the countries of the former Yugoslavia (87. $7 \%$ ), then there are citizens of the European Union (6. 5 $\%$ ) and others (5.8\%). Therefore, the Centre for Slovene Language offers possibilities for learning Slovene language as a non-first language for all residents of Slovenia whose mother tongue is not Slovene. So, throughout the whole year, the Centre for Slovene Language carries out classical language courses of Slovene language (Autumn School, Spring School, Morning Course, etc.) and specialised courses intended mostly for gaining knowledge for the Basic Level Exam, the Intermediate Level Exam or the Advanced Level Exam. Since the mentioned language courses are payable, they are not available to all residents of Slovenia who would like to learn Slovene. Hence, between the years 2012-2014, the Centre for Slovene as a Second/Foreign Language, carried out a programme called Initial Integration of Immigrants which was free of charge for the participants. Its goal was language integration of foreigners. Foreigners with permanent or 
temporary residence in Slovenia were able to participate in the language course (if they met certain conditions). Some activities of the Centre for Slovene as a Second/Foreign Language focus mainly on the youth, to help them develop linguistic communicative abilities and consequently enable them full (co)operation in Slovenian society.

\subsection{Programme Slovene for Children and Teenagers}

The Centre's programme Slovene for Children and Teenagers combines activities connected with teaching teenagers Slovene language as a second/foreign language. This programme includes: Slovene Language Youth Summer Schools, Intensive Weeks for Pupils of Slovene and Slovene Courses for Elementary and Secondary School Pupils and Immigrant Parents. Intensive Weeks of Slovene Language is a 30-hour long Slovene language course intended for elementary and secondary school pupils of bilingual schools, or for remedial classes of Slovene language abroad and in immigration. In the school year 2012/13, the Centre for Slovene as a Second/Foreign Language organised intensive language courses of Slovene language for teenagers who wanted to learn Slovene language as quickly as possible. During the initial stage of the language course, the participants acquainted with the communicational patterns relevant for integrating in school and social life, and learned basic grammatical structures. These language courses intended for immigrants (children and secondary school pupils and their parents) are extremely important. Nataša Pirih Svetina (2008: 147-148) believes that:

The problematic of integrating migrant children into the Slovene school system is a topical issue. In this very subject field, the first and most needed language-political actions - including changing legislation and school rule books - will be needed, if Slovenia wants to ensure social peace and prevent the Slovenian school system from simply rejecting anybody who is ignorant of the Slovene language.

For the proper integration of children whose mother tongue is not the Slovene language, teachers of Slovene Language and Elementary Education who are acquainted with the problematic and educated or trained for 
working with such vulnerable target groups, are needed. Mihaela Knez says that we need well-educated teachers, since the current ones mostly are not suitably trained for teaching Slovene as a second language. The Slovene Language study programme or the Elementary Education study programme (let alone other study programmes) do not include subjects such as the methodology of teaching Slovene as a second language. This is why she recommends that such contents should immediately be included in the study programmes (or that vocational teachers should be offered a possibility of additional education in this field) (Knez 2008: 162). For these reasons, the Centre for Slovene as a Second/Foreign Language organises a series of specific training programmes and seminars intended both for teachers of Slovene Language abroad and in immigration, and for teachers in Slovene schools who face linguistically non-homogeneous groups of children and teenagers.

\section{Activities, intended for minorities abroad}

The Republic of Slovenia preserves Slovene language among Slovene minorities abroad with two basic programmes - both financed by the Ministry of Education, Science and Sport. One is in the domain of the National Education Institute Slovenia, the other in the domain of the Centre for Slovene as a Second/Foreign Language.

\subsection{Remedial classes of Slovene language}

Julijana Vučo (2012: 19-20) says that:

The life force of languages attests itself most where it is supported /.../ by definite strategies of promoting a language abroad and supporting teaching of this language as a second language (L2), following globally recognised standards of certification and evaluation, and designed language politics that concerns members of ethnic and national communities etc.

According to the latest available data, at the moment, approximately 500,000 Slovenians and their progeny live outside Slovenia.Since preservation of mother tongue and culture constitute a basic human right, they should have an opportunity to preserve Slovene language and culture with 
the help of Slovene language classes made available by the Republic of Slovenia. The programme is called the Slovene Language for Slovenians Abroad which is financed and organised by the Ministry of Education, Science and Sport of the Republic of Slovenia and the National Education Institute Slovenia that provides the content part of the programme (curriculum, programme, textbooks) , and cooperates with the Centre for Slovene as a Second/Foreign Language (Bitenc 2000: 59). In Europe, the programme is called Remedial Classes of Slovene Language, while in Northern and Southern America and in Australia (areas where a large part of the Slovene non-European diaspora lives), so called "Saturday Schools" are organised. In the year 2014/15, Remedial Classes of Slovene Language took place in Austria, Belgium, Bosnia and Herzegovina, the Czech Republic, France, Croatia, Liechtenstein, Macedonia, Germany, the Netherlands, Serbia, Switzerland and Great Britain. It is a voluntary activity that (usually) takes place once a week in the afternoon. And who are the teachers that teach Slovene language in both mentioned programmes? Teachers of remedial classes are full-time employed teachers of Elementary Education or Slovene Language in Slovene elementary or secondary schools and have at least three years of professional experience. If they are chosen to teach remedial classes, the National Education Institute Slovenia adequately educates them and refers them to one of the countries where remedial classes take place. Beside basic knowledge, teachers must also have knowledge of the host country and a well-developed intercultural skill to understand and respect their own culture and that of the others. In some countries (principally in Germany and Austria), language classes are under foreign jurisdiction, while elsewhere they are under the jurisdiction of the country of origin - Slovenia (Bitenc 2000: 59). Overseas, Saturday Schools are usually taught by teachers of Slovenian descent. They are salaried by the Republic of Slovenia, but are not, as teachers of remedial classes, employed in Slovenian schools. Teachers of remedial classes use a curriculum for Slovene language as a minority language which is described below.

\subsection{Curriculum for Slovene language as a minority language}

The personal and social circumstances of children and adults who are learning Slovene language abroad are very different from those who grow 
up and learn the language in an environment where Slovene language is an official and communicative language of the majority of population - as in Slovenia. Hence, the National Education Institute Slovenia prepared three special curriculums within the programme Slovene Language for Slovenians Abroad. These are: the curriculum for immigrants, curriculum for elementary school and curriculum for secondary school. The curriculum for immigrants is divided into three linguistic and age levels: lower, medium and higher linguistic/age level. The lower level acquaints students with subjects for basic communication, like family, colours, food, clothes and school. The medium level subjects are focused on developing intercultural communication skills. Medium level subjects are: family relatives, holidays, interculturality, food as an expression of a cultural and natural environment etc. Higher level remedial classes include the following subjects: my friends (bi-culturality), colourfulness of the landscape (description of places, cities), geographical, historical and cultural characteristics of the home country and Slovenia, tolerance towards being different multiculturality. All subjects should be developed through project work. In practice this means that children, for example, talk about Shrovetide and Shrovetide customs, then they learn about typical Slovenian masks (for instance the Kurent carnival figure), find parallels with their culture (in Serbia, for instance this figure could be the so-called Ovčar) and then they make their own Shrovetide masks. The curriculum for immigrants is intended for pupils who learn Slovene language once a week and attend it as a non-obligatory/elective class subject. For elementary and secondary school pupils who learn Slovene several times a week, two curriculums were prepared: a curriculum for teaching Slovene language for elementary pupils outside the Republic of Slovenia and curriculum for general secondary schools. This curriculum is similar to the curriculum intended for children who learn Slovene language as a mother tongue in Slovene elementary schools. The curriculum defines general and specific educational goals. General educational goals are: creating a positive emotional relationship with the Slovene language, developing communicational skills, preserving and developing a positive relationship towards reading and gaining literary knowledge. Since this curriculum is intended for children who study Slovene several hours per week, it is a lot more accurate and differentiated (by topic and by educational goals). The curriculum for general secondary 
schools is defined in its introduction as a curriculum for Slovene language classes abroad (that) complies with the specific of teaching abroad and is designed in a way which allows inclusion in various schooling programmes (like Slovene general secondary school, international "matura" examination). It includes the same general goals/competences as the curriculum for general secondary schools, but due to a smaller number of lessons and specific subject work methods, some changes exist.

\subsection{Slovene at Foreign Universities}

As mentioned before, the programme Slovene at Foreign Universities is one of the basic programmes of the Centre for Slovene as a Second/ Foreign Language. It is a network of Slovene lectureships all over the world, from Buenos Aires to Tokyo. Slovene lectureships abroad are not directly connected with Slovene minorities outside Slovenia but this does not mean that there is no connection at all. Some lectureships, like the ones in Buenos Aires and in La Plata were particularly organised because of the presence of a strong Slovenian community in this country. Foreign universities hire teachers of Slovene language employed by the Faculty of Arts in Ljubljana, who are then sent to the Host University or foreign universities. In both examples, they are connected with the Centre for Slovene as a Second/Foreign Language. Twice a year, the Centre organises a specialised training course for teachers of Slovene language who teach at foreign universities and which considers and presents the latest pedagogical, Slovenistic and other linguistic, but also organisational (etc.) questions. Besides the educational role, the Centre for Slovene as a Second/Foreign Language also has a strong connective mission - to befriend (due to before mentioned obligatory training courses) teachers of Slovene language which represents a great added value. Besides that, the Centre organises and coordinates big collective projects with the goal of increasing Slovene language recognisability and promotion. At the moment, the most recognized project of this kind is World Days. In 2014, World Days of Slovene Language took place. Within this project, a booklet Pocket Slovene was published (in 22 languages). Participants and students that attend Slovene language classes at foreign universities are therefore actively included in all major projects what gives them special value. 


\section{Conclusion}

We can conclude that the Centre for Slovene as a Second/Foreign Language and the National Educational Institute Slovenia provide a continuous and a systematic development of Slovene language as a second and a foreign language in Slovenia and abroad. At the same time they also support Slovenian minorities around the world. If we return to Julijana Vučo's quote that the life force of languages attests itself mostly where it is supported by a designed language politics (2012: 19-20), then we can say that the Slovene language is definitely a vital and strong language with incredible potential. We can only hope that this potential will be realised. This can only be done, if the Republic of Slovenia is willing to invest in this purpose with human and material resources. In this case, minorities in Slovenia and abroad will not be afraid for their existence and development.

\section{References:}

Bitenc, Maja (2006): Slovenščina in njeno poučevanje pri slovenskih zdomcih: raziskava med učenci do polnilnegapouka slovenskega jezika in kulture v Baden-Wüttenbergu. Jezik in slovstvo 51, No. 3/4.

Knez, Mihaela (2012): Za koliko slovenščin(e) je prostora v naši šoli? Jezik in slovstvo 57, No. 3/4.

PirihSvetina, Nataša (2008): Slovenščina v mobilnosti, mobilnost v slovenščini (slovenščinakot J1, J2 in TJ). Jeziki v izobraževanju: zbornik prispevkov konference (Ed. Milena Ivšek). Ljubljana: Zavod RS zašolstvo.

Vučo, Julijana (2012): O učenju jezikov: pogled v zgodovinoglotodidaktike: od pradavnine do drugesvetovnevojne. Ljubljana: ZnanstvenazaložbaFilozofskefakultete.

\section{Internet sources:}

Office for National Minorities of Republic of Slovenia (Urad Republike Slovenije za narodnosti). www.un.gov.si. 2. 4. 2015.

Statistical Office of the Republic of Slovenia, year 2011 (Statistični urad Republike Slovenije) www.stat.si.10. 4. 2015. 
National education institute Slovenia (Zavod za šolstvo Republike Slovenije). www.zrss.si. 10. 5. 2015.

Centre for Slovene as Second and Foreign Language. (Center za slovenščino kot drugi in tuji jezik). www.centerslo.net. 15. 5. 2015.

Office for Slovenians abroad (Urad za Slovence po svetu) www.uszs.si. 15. 5.2015

Curriculum for general secondary schools eportal. (Učni načrt za gimnazije) mss.edus.si 15. 5. 2015

\begin{abstract}
The article presents the main activities of the Centre for Slovene as a Second and Foreign Language, which operates within the Department of Slovene Studies at the University of Ljubljana's Faculty of Arts. The members of the Centre put the main focus on teaching Slovene as a foreign language abroad and also in Slovenia. Furthermore, with the National Education Institute of the Republic of Slovenia, they also endeavour to establish and develop lessons of Slovene as a minority language. Accelerated courses of Slovene language are organised for primary and secondary school students of Slovene and also for bilingual schools. Furthermore, primary and secondary school students and older immigrants can attend the Slovene lessons as well. Immigrant children who are included into the Slovene educational system, and their parents, are the target group of the activities organised by the Centre.
\end{abstract}

Keywords: Slovene as a Second and Foreign Language, Minorities in Slovenia, Centre for Slovene as a Second and Foreign Language.

\title{
Biographical statement
}

MR LAURA FEKONJA is a Lecturer of Slovene Language at the Department for General Linguistics at the Philological Faculty University in Belgrade. She has teaching experience as a Lecturer in the Czech Republic, Croatia and Austria. Her research interests include second language acquisition and error feedback to second language learners and their attitudes to such feedback.

E-mail: laura_fekonja@hotmail.com 